\title{
国立がんセンターにおける骨腫陽の統計
}

\begin{tabular}{|c|c|c|c|}
\hline \multirow[t]{3}{*}{ 国立がんセンター整歼外科 } & 前 & 山 & \\
\hline & 福 & 間 & 久 \\
\hline & $f_{i}:$ & 灥 & $\equiv$ \\
\hline
\end{tabular}

\section{Bone Tumors at National Cancer Center Hospital \\ By}

\section{Maeyama, H. Fukuma and S. Sato}

Bone Tumor Service, National Cancer Center Hospital

昭和 37 年 5 月末 国立がんセンターが開設されて以 来, 寕和 38 年 3 月末に至る約 10 力月の間に本院を副 机た外来患者数は総淤 13,339名で，乙の小骨腫瘍の筑 嚋に入るもののみを抽出すると, 表 1 の如く骨に原発 するむの 19 名, 続発性のむの 139 名で計 158 例にお よんでいる.

前者の中には Fibrous dysplasia, Chondrosarcoma, Fibrosarcoma, Plasma cell myeloma, Hemangioendothelioma および Ewing's Sarcoma それ ぞれ 1 例宛, Osteochondroma, Giant cell tumor, Ossifying parosteal sarcoma それぞれ 2 例および

表 1 Bone Tumors at National Cancer Center Hospital. May, 1962 March, 1963

Primary Neoplasms of Bone Osteochondroma 2 cases

(Solitary Cartilaginous Exostosis)

Fibrous Dysplasia

Giant Cell Tumor

Osteogenic Sarcoma

1

Chondrosarcoma

Fibrosarcoma

Ossifying Parosteal Sarcoma

Plasma Cell Myeloma

Hemangioendothelioma

Ewing's Sarcoma

Secondary Neoplasms of Bone

Benign Synovioma 1

(Localized Nodular Synovitis)

Malignant Neoplasms

Total 158 cases
Osteogenic sarcomaの 7 例を念み, 後者の群には 良性の所謂 Benign synovioma 或いは Localized nodular synovitis と呼ばれるもので骨侵触を伴つ たむの 1 例の他は主として癌の骨転移による悪性の骨 病変を示すむの 138 例である. 骨に原発する腫瘍のう ち興味あるむのの 2,3 を挙げる.

\section{1. 巨細胞腫}

症例 1 は 19 才の 우, 右大腿骨下端の巨細胞腫とし て，放射線科にてコバルト約 $3000 r$ を照射後経過観察 巾のあので, 既に症状は昭和 32 年の末より始まり, 33 年末より東京厚生年金病院で同様澎断のトにレ線 治療を試みられているが, 発症が患者 14 才で比較的 若いこと，レ線像で所々骨濃影を有する吸収像を示す ことから, 照射治療によつても吸収像の拡大増加な く, むしろ多少治痛機転が窥われることとも相俟つ て，巨細胞腫との診断には一抹の危惧がおかれる症例 であるが，患者は適令期のため可及的に一切の手術的 侵襲を避けたいので, 経過観察のみに止めている.

症例 2 は 27 才の方, 脂利 36 年 8 月跛行を指摘され 翌年 2 月には疼痛のため歩行不能となり東京医科崡科 大学で骨病変を発見され, その後名含病院で巨細胞胿! の汪断を碓定して择爬骨移植を行なつたに拘らず病具 朢化し，才大転子部が著しく腫脤するに至つたもので 顺和 37 作 11 月当センター来院，12月に Vitallium の Austin Moore Prosthesisによる骨頭置換術走行 ない, 現在多よ゙無杖にて歩行可能の症例である.

組織学的には線維沟腄様の悪性像を所々に認めうる

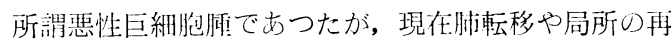
発は認めない。 


\section{2. 骨原性肉腫 Osteogenic sarcoma}

朁に他の病院で切断され，䉼端再発におよんで放射 線治療などに期街して木院を訪机るむのが多いが，症 例 3 は 5 才 2 月の号，坿和 37 年 5 月易根中央病院で 闪腫上涁断され当センターで 6 月切断された左大腿浞 卜㳩监の骨形成性骨肉腫で，術後エンドキサンなどが用 いら机ているが, 退院後玉造病院で肺転移が見计され たという。

症例 4 は直接我々が治療に当つたもので, 14 才り ，四国宇利舁から上京してきた左脛骨々肉腫の患考 で，朋利 37 年左下腿上部に腫張上疼痛が始まり, 宇 利鼠市立病院より当センターに送られてきたもので， 術前コバルト 1640 照射後炤利 37 年.10月 左大腿中内 部にて切断, 術後マイトマイシン $90 \mathrm{mg}$ を投与, 現在 異常の報に接しない。組織像では chondroblasticな 個所が多く，また照射のためか腫瘍細胞は極めて膨大 変性し, 遊離の傾向功つよい。

光例 5 は 53 才の令で，頙蓋骨に巨大な吸收像を小 し, Hand-Schüller-Christian 氏病, Meningioma 或 いは癌転移などが当センターのメディカルカンファ レンスでは疑わ机たが, Biopsyで Fibrosarcoma な る病理獄断が与えられたむのである。然しながら，組 織像の検行の結果, 䋐維性組織のところじころには㭃 若な骨新生が涩めら机，むしろ Osteogenic sarcoma の中に入れた方が正確である.このような高令者の䫓 蓋の肉腫はPaget 氏病に由来するものが大半を泫め ると言わ防るが，この症例ではその裹付けが見出し難 w.

\section{Ossifying parosteal sarcoma}

Parosteal osteoma と呼ばれる比較的良性の腫煬 は一般に桸な型の肉腫であるが, 我々は既に九大整形 外科の登録例として 2 例を報告しているが，幸いにむ 当センタ一赴任以来知期間の中に定型的な 2 例を経験 した。症例 6 は 13 才の占で, 炤利 37 件 7 月朋を組ん だところ右大腿下部の疼痛がおこり，8月当センター 受渗, 大腿下端注球状の境界稍。不明膫な骨陰影を大 腿胃の後内側, 罗接着して筋肉内に認める. 一見し て Parosteal osteoma と考えられるが, 当時整形外 科末開設で，外科の医員の于でその上部で切断さ机て いる，組織像では一部幻若増殖像をみるが，大部分は 成热分化した骨梁，線維性間貿，ところこここに軟留

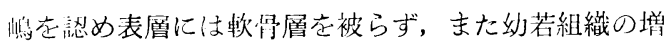
外屯涩めない。現在肺転移，䉼端の再発なく，義肢装
用して元気に通学中である.

症例 7 は国立身体障碍者更生指導所の入所生で, 2 才のときポリオに䍜患, 左下肢の別緩性麻㾇の患者 で，既に同所にて昭利 26 年 左足関節固定術などが行 なわ机ている。顼和38年 1 月誘因なく存大腿外侧の疼 痛上腫脹あり, レ線像にて大腿骨大転子下方に化骨性 筋炎に似た淡い骨陰影が出現徐々に増強している. 3 今当センター入院, 腫瘤の剔出を行なつたが, 腫瘍は 大腿盈大転子下方の骨皮質の一部に基底を有して細長 くト方にたれトつた小指大の硬い腫瘍で, 周囲筋肉之 は被膜を以つて境され容易に分離しうる. 基底部を大 腿骨々皮質の薄層を今念めて切離し, 腫瘍を摘出するに 大腿盈々皮質は他部之外見上変化はない。腫瘤の組織 像は表層は薄い横骨梁で被われ, その外側は骨膜性組 織で，一部に細胞の増殖をみるむ軟骨層をみない。ま た, 内部は大部分分化せる骨梁と線維性組織で, 一部 に幼若骨梁新生域をみとめこの部の細胞增殖は強い. 木例は術後一力月にして再び切離せる基底部に相当し て淡い小陰影の発生をレ線像に認め, 再び手術を行な つたが, 前回切除部よりやや中枢側大転子に近く骨皮 兵から扁半汇隆起する母指頭大の骨増殖を認めたの で，この部を周囲骨皮質を充分厚く含めて切除した。

\section{Hemangioendothelioma}

省に発生する Hemangioendotheliomaは最近認識 を新たに注目されてきた腫瘍で，発生部位ではその治 療も比較的容易であるし，またその性格も一概に悪性 とはいつても経過は比較的緩慢で転移も起し難い. 症 例 8 は 11 才の方，小児科の患者で，炤和 35 年尾底骨 在強打して以来腰痛跛行が始まり, 昭和 35 年 7 月レ 線像で, 腰椎下部に変化を認め試切の結果 Hemangioendothelioma と衫断され昭和 37 年 8 月当センターに 入院したもので, 手術の適応がたてられぬまま, エン ドキサン $2,600 \mathrm{mg}$ 径四投与や Co $2,10 \mathrm{Cr}$ の照射が行な われたが，後者が一般的に症状の緩解をきたし得た他 は著効なく，発症後約 3 力年にて，尿閉，下肢麻㾝な よ゙をきたして死亡している。

\section{Ewing 氏肉腫}

本例む小児科担当の患者で 1 才 8 力月の方，生後 6 今增銧骨上窝淋区線の腫倀に気付き試切の結果 Ewing 上肉腫之判明, 腼利 37 脌: 7 月当センターに入 院， $\mathrm{Co}^{60}$, ナイトロミン，マイトアイシン，エンドキ サン，ノレドニンなどを投方したが，一方的に悪化 し，9月鬼籍に入つた例で，原発は右脛骨と考えられ 
るが既に両大腿骨, 骨盤, 両上肢, 頭蓋抢よび胸㴌, 奉柱周辺と全身に波及している。副堅に腫瑒なく, 縕 織像でも真性のロゼッテ形成をみず Neuroblastoma と区別された。

次に骨以外の他臟器に発生した腫瘍が，遠隔位の骨 に転移したり，或いは骨周辺の腫場が接する骨を侵蝕 あるいは厅迫吸収したりする所謂続発性の骨腫汮の中 には種々雑多なすのが含まれうるが，当センターでは

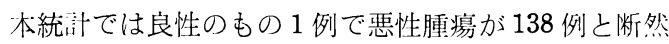
多数を示すが，てれはまた現段階における当センター 病院の患者の特色の一つを表現するものとも言える.

\section{Benign synovioma}

滑液膜組織に由来する組織としては色素性䋐毛性滑 液膜炎之か，コレステロール沈着を中心とする腱の所 謂 Xanthofibroma などの他に，恐らく関節洞液膜か ら発生したと考えられる一種の腫瘍 Benign synovioma 屯含まれ，乙れはまたてれら腫瘍を一括して炎 症説を唱える Jaffe らにとつては局在性結節性滑液 膜炎として挙げられている。このやのあるものは骨吸 収像を招来するあのがあり，我々はたまたま批に発 生した本例を経験した。

症例 10. 40 才の古, 18 才のとき左環指の第 1 指関 節部を強打腫脹をきたしたが，障害なく放置せるとこ 万最近 4 力月前より腫脹増加し鈍痛を泝えるようにな つて当センタ一に来院，上線像指骨々頭に蜂窝状吸収 像を認め, 軟骨腫, 骨囊腫あるいは巨細胞腫などが疑 われたが，于術にて関節周辺の灰黄色腫舅が指骨遠位 端を背側より侵蝕空洞を形成し, 組織像では始め巨細 胞腫との病理所見であつたが，ある時期に至り企く 別個に病理ならびに我々の見解が木例は所謂 Giant cell xanthoma 乙屯呼ばれる局在性結節性滑液膜炎 で, 性格の上からはむしろかかる例は Benign synovioma なる表現が最む適切であることにそれぞれ偶 然に一致した興味ある症例である.

直接または間接に悪性腫瘍による骨の二次的病変を おこすすのの中には各臟器の檀が骨に転移したものが その大部分であるが，中にはこれらの癌が，その位置 的関係上直接骨を侵すむの屯極く少数ながら存在す る. 就中上顎ならびに下顎癌などはその大部分が後者 汇属する.

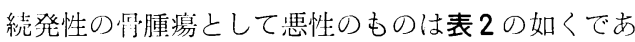
る.

この中, 骨転移を伴つた癌の各臟器別の骨転移発生 率をそれぞれのグループ 10 例 以上のむののみについ
表 2 Malignant Neoplasms with Bone Involvement

\begin{tabular}{|c|c|c|c|}
\hline & & $\begin{array}{r}\text { Bon } \\
\text { Involve }\end{array}$ & ment \\
\hline & total & no. & $\%$ \\
\hline Digestive Tract & & & \\
\hline lip & (4) & 0 & 0 \\
\hline tongue & (37) & 1 & 2.7 \\
\hline salivary glands & (5) & 2 & 40.0 \\
\hline lower jaw & (5) & 2 & 40.0 \\
\hline oral cavity & (17) & 1 & 5.9 \\
\hline tonsil & (2) & 0 & 0 \\
\hline phalanx & (27) & 3 & 11.1 \\
\hline esophagus & (71) & 3 & 4.2 \\
\hline stomach & (468) & 2 & 0.4 \\
\hline bowel & (14) & 0 & 0 \\
\hline rectum & (71) & 3 & 4.2 \\
\hline gall bladder & (3) & 1 & 33.3 \\
\hline liver & (15) & 1 & 6.7 \\
\hline pancreas & (9) & 0 & 0 \\
\hline peritoneum & (5) & 0 & 0 \\
\hline Respiratory System & & & \\
\hline upper jaw & $(38)$ & 26 & 68.4 \\
\hline $\operatorname{larynx}$ & (39) & 1 & 2.6 \\
\hline lung & $(120)$ & 13 & 10.8 \\
\hline mediastinum & (6) & 1 & 16.7 \\
\hline Mammary Gland, Genito- & drinary 1 & Tract & \\
\hline breast & $(172)$ & 30 & 17.4 \\
\hline uterus & $(158)$ & 5 & 3.2 \\
\hline ovary & $(8)$ & 0 & 0 \\
\hline vagina, vulva & (8) & 0 & 0 \\
\hline prostate & (14) & 6 & 42.9 \\
\hline testis & (16) & 1 & 6.3 \\
\hline penis & (8) & 0 & 0 \\
\hline kidney & (13) & 2 & 15.4 \\
\hline urinary bladder & (12) & 1 & 8.3 \\
\hline Skin & (28) & 4 & 14.3 \\
\hline Eye & (8) & 3 & 37.5 \\
\hline Brain & (17) & 1 & 5.9 \\
\hline Endocrine Glands & & & \\
\hline thyroid & (27) & 3 & 11.1 \\
\hline suprarenal & (1) & 1 & 100.0 \\
\hline Connective Tissue & & & \\
\hline fibrosarcoma & (2) & 1 & 50.0 \\
\hline rhabdomyosarcoma & (4) & 2 & 50.0 \\
\hline synovial sarcoma & (1) & 0 & 0 \\
\hline Vascular Tissue & & & \\
\hline angiosarcoma & (2) & 0 & 0 \\
\hline Hematopoietic Tissue & & & \\
\hline reticulum cell sarcoma & $(22)$ & 1 & 4.5 \\
\hline Hodgkin's disease & (2) & 0 & 0 \\
\hline leucaemia & (13) & 3 & 23.1 \\
\hline other malignant tumors & (43) & 4 & \\
\hline Total & $\begin{array}{l}\text { cases } \\
1535\end{array}$ & s $\begin{array}{c}\text { case } \\
138\end{array}$ & es 96 \\
\hline
\end{tabular}

て挙げると表了の如くである.

即ち前立腺癌に最屯骨転移率が高く, 次いで乳癌, 紧臓腫瘍（転移例はいずれも Grawitz 氏腫瘍）で, 胃癌患者の骨転移の発見は最む少なく僅かに 468 例中 
表 3 Carcinona with Bone Metastasis

\begin{tabular}{|lrrl|}
\hline Primarys ites & (total cases) & metastatic cases \\
1. Prostate & $(14)$ & 6 & $42.9 \%$ \\
2. Breast & $(172)$ & 30 & 17.4 \\
3. Kidney & $(13)$ & 2 & 15.4 \\
4. Thyroid & $(27)$ & 3 & 11.1 \\
5. Pharynx & $(27)$ & 3 & 11.1 \\
6. Lung & $(120)$ & 13 & 10.8 \\
7. Urinary Bladder & $(12)$ & 1 & 8.3 \\
8. Liver & $(15)$ & 1 & 6.7 \\
9. Testis & $(16)$ & 1 & 6.3 \\
10. Oral Cavity & $(18)$ & 1 & 5.6 \\
11. Esophagus & $(71)$ & 3 & 4.2 \\
12. Rectum & $(71)$ & 3 & 4.2 \\
13. Uterus & $(158)$ & 5 & 3.2 \\
14. Tongue & $(37)$ & 1 & 2.7 \\
15. Stomach & $(468)$ & 2 & 0.4 \\
\hline
\end{tabular}

2 例 $0.4 \%$ にすぎぬ. 乙机は各蔵器舟の特殊性という 他に, 患考の受沴の時期や術後の経過観察の機会など の外因的な関係も考虑されなり机ばならぬ.

症例11. 前立腺癌の骨転移の多くは骨硬化型の転移 坚を示すことが特色があるが，木例はその最む顕荠な 例で, 71 才の方, 昭和 32 年.久留米大学で前立腺剔出 以来 Castration やホンバン, 放射線治療などで経過 良好であつたが，䀠利 37 年背痛を、派元大龺田市永田 整形外科で骨転移を発見，当センターに入院したもの で, 腰椎, 骨盤, 大腿骨, 頭蓋などに骨硬化性転移架 をみる.組織像でも著明な骨䚲成を腫瘍細胞の間に認 めた.アルカリフォスファターゼや酸性フォスファタ 一ゼの著しい上㘹をみる。

症例12、次いで高い骨転移沸老示す乳癌の大部分は osteolytic な所見を示すあのが大部分であるが，時 化硬化性レ線像安みるあのあある。本例は前記前立腺 癌の骨転移例上同じような著明なレ線像を示す汯化型 転移で昭和 37 年. 8 月左乳璄の根治于術を行ないその後 頚蓋, 脊椎, 能愁, 助骨, 大腿骨などに大小门形の転 移坚がボタン雪在散らしたような濃影で散在するのを 热め, アルカリフォスファターゼは中等度に上則する が，酸性フォスファターゼは止常域に止まる。

症例 13 は著明な骨吸収紧を右大腿骨々幹部に小 し，既に他院にて biopsy の結果グラビッッ氏腫場の 渗断が確定していたが，元の後左坐骨にも同様転移柴 を涊め, 督腫湯剔出術後数日にして死亡した。

症例14 46 才の令 左晹骨の甲状腺癌転移で osteolyticな吸収巢症示し，症例 15 もまた肺癌の右尺骨
転移である。

症例 16 は 55 才の 才, 昭和 38 年 2 月肺癌を疑つて 来院したが, 途中激烈な腰痛のため, 胸部の精渗が出 来ず整形受診, 当時腰椎汇著変なく骨盤率引にて軽快 したが， 4 月には第 2 腰椎の压潰が認められるに至 り，また肺癌の診断も碓定された。

尚肺癌の患者で四肢長管骨の肥厚とと屯に指端肥大 を示す所謂 Hyperostosis pulmonaris の症例は既に 注目されるところであるが, 症例 17 はその例で，49 才令肺癌, 骨転移はみないが上下肢, 手指などに骨 膜性肥厚を認め，また顕著な末端肥大を于手指にみる。

次に骨転移を起とした腫瘍として, 極めて珍らしい Retinoblastoma および Rhabdomyosarcoma の症例 を供覽する。

Retinoblastoma とは殆んど 4 才以下の幼児に発生 する腫瘍で胎児期の Retina に由来し, 屡々家族性に 発生する極めて稀な腫瘍で, 米国では新生児 34,000 人 中 1 例の㕩で発生するという. 眼球全組織を侵して早 くより眼球突出をきたし，眼窠を構成する骨を侵す. 18壮紀後半よりGraefe, Virchow, Flexer, Ginsberg, Fisher および Verhoeif 等によりいろいろな名称で 呼ばれたが，1922 年 Verhoeffは “Retinoblastoma” として独立疾患に分類した. 未期には骨, 淋巴腺, 肝 などに転移する䛉載はあるが，骨転移像についてその 洋細な症例報告は未だ見出し得ない。

症例 18 は Retinoblastoma の骨転移をきたした貴 重な 1 例であるが，当センターには同疾患 4 名中他の 3 名には萷転移を見出していない。本例は 2 才 2 力月 の早, 昭和 36 年 4 月即与生後 7 月頃右眼の猫眼に気 付き, 昭和 36 年 11 月末庱大にて Glioma retinae の 渗断下に眼球剔出, 組識学的に Retinoblastoma 上さ れた. その後, 再発, 颜清術, Co 照射などを行なつた が再び再発して昭和 37 年 9 月当センター入院 $\mathrm{Co}^{60}$, 4650rにて眼窠の腫湟は一旦消失したが，昭和 37 年 末加ら昭和 38 年 1 月に加けて右煩部, 右顎下淋巴腺 の腫脹とともに健側眼球む乫出するに至り, また頭蓋 に多数の腫瘤をみるに至つた。レ線像では特に骨転移 像として両上腕骨の近位メタフィーゼから骨幹にかけ て特に外骨膜性の変化即ち Onion-layer と Spicula の䋊細な交錯像が坐骨, 大腿婴メタフィーゼなどにあ 骨病変をみる. 特にこの上腕骨転移像は美麗で, 貴重 な資料である. 組織学的には Neuroblastoma 似て echte Rosette を形成し，細胞は濃厚な核と乏しい細 胞質を特長とする. 
症例 19 は 1 年 10 月の ㅇ, 昭 37 年末発熱, 両眼瞼腫 脹, その後下肢の疼痛のため跛行を招来したが, プレ ドニンの投与で軽快したが 昭和 38 年 2 月末額, 眼瞼 腫脹, 眼球突出し, 目がみえなくなり始め，3 月13日当 センタ一訪院, アリカリフォスファターゼが 4.9 とや や上昇している.レ線像では眼窩後方の頭蓋底の不鮮 明化とともに両上腕両下肢に外骨膜性の Onion-layer を伴う intramedullar の骨吸収の多数の微小陰影を 認める.

当センターのメデイカルカンファレンスでは Sarcoma, Neuroblastoma が疑われたが, 頭部淋巴 Ewing's 腺腫大の Biopsy で Rhabdomyosarcoma が最も疑われるといい現在組織学的に尚検討中であ る. 当センターには Rhabdomyosarcoma の 4 例が あり内 2 例に骨転移をみている.

小児に発生する腫瘍として悪性のものは骨原性骨肉 腫を除いた場合 Ewing 氏肉腫, Neuroblastoma お よび Rhabdomyosarcoma などがあるが，これらは 細胞学的にも所謂円形細胞肉腫に属し, 可成りの相似 点を有するが，その骨病変のレ線像むまた極めて類似 し，鑑別が容易でない.
以上昭和 38 年 3 月末までに当センタ一病院を訪れ た骨腫瘍患者は総計 158 例におよび，その種類も上述 の如く比較的稀で興味あるあのを有している.

悪性の骨腫瘍のみについて言えば総数 152 名で, こ れは同期間中の外来総数 13,339 名の $1.1 \%$ に相当し またその中の悪性腫痬 1,546 例の $9.8 \%$ \%たる.

当センター病院の入院患者は現在, 胃, 乳, 肺, 子 宮癌などが大部分で, 骨腫瘍患者の数は未だ少数であ るが，一般の認識とともに今後益々増加するあのと期 待され，全国整形外科医各位の御協力をお願いすると ともに，本年度整形外科学会総会の要望により全国骨 腫瘍登録センターを本センター内に設立する運びとな つたととは感謝の至りである。

追加およひ兵問 熊本大学 玉 井 達 二

Hyperostosis pulmonalis は肺結核, 縦隔䁇腫瘍に あ見られるし，指の膨大む見られる．乙の場合骨に疼 痛を泝えるものがあるが肺癌の場合には疼痛を泝える か.

答国立がんセンター 前 山 厳 本例は骨転移をみるため全身骨のX線写真を撮つて 発見したもので疼痛に関しては特に記憶しない。

\section{Bickel, Moe 手術とその適応}

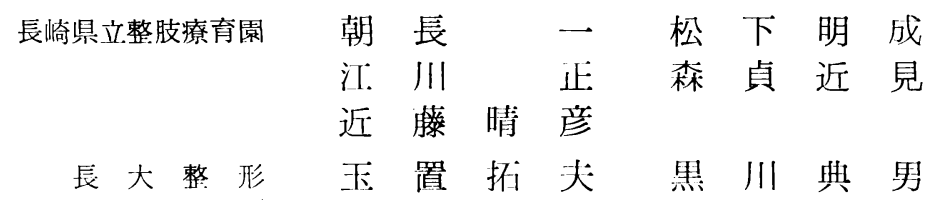

Bickel, Moe's Operation and its Indication

By

\section{H. Tomonaga, A. Matsushita, T. Egawa,}

C. Morisada and H. Kondo

Nagasaki Prefecture Crippled Children's Hospital

\section{T. Tamaki and N. Kurokawa}

Department of Orthopedic Surgery, Nagasaki University, School of Medicine

はじめに

下腿三頭筋の麻㾝は単に踵足変形を来すだけではな
く, 人間の基本的な動作の一つである直立位保持や， dynamic, automatic な歩行に対して重大な障碍をお よぼす. 即ち heel and toe gaitは失われ,けり出 